\title{
Traditional Elites between Bullets and Ballots
}

\section{Elections in south-eastern Afghanistan}

\section{Summary}

Successful elections and political transition in 2014 are crucial for the future relationship between Afghanistan and the international community.

Traditional elites, however, are somewhat ambiguous vis-à-vis elections, given that many perceived the failure of the Afghan government to deliver on past elections promises-mostly in the form of development assistance-as a deal-breaker of the social contract that underpinned their relationship with the state. As a result the legitimacy of election processes-and by association the Afghan state-is weak in the rural Southeast.

Nevertheless, while negatively reflecting on their experience in past elections, many rural elites are currently reactivating old networks in preparation for 2014 elections. In contrast to previous elections, however, influential traditional elites in Khost and Paktia are investing their political and social capital in the campaigns of presidential or parliamentary candidates rather than more local provincial council elections.

However, Provincial Council elections do seem to present a platform for less wellknown public figures and young civil society activists to increase their public visibility.

\section{HEINRICH}

BÖLL STIFTUNG

The Liaison Office is grateful to funding provided by the Heinrich Böll Foundation AFGHANISTAN

\section{Introduction}

The Afghan Presidential and Provincial Council elections set for 5 April 2014 are a hot topic among local and international stakeholders. ${ }^{1}$ Though much remains unclear, there is one certainty in elections: they create losers and winners, and depending on the number of candidates or teams running, losers often outnumber winners. Given that the incumbent President (Hamid Karzai) is constitutionally not allowed to run for a third term, the upcoming presidential election is in many ways "a 'make or break' event;" ${ }^{2}$ one linked not only to an important internal political transition, but also with the potential to shape future international engagement with the country.

Indeed, many Afghans consider this particular election and political transition an important game changer for their country-possibly more so than the first election in 2004-and closely related to the current security transition. "As NATO troops withdraw in the lead up to the end of the coalition's combat mission in December of 2014, the upcoming elections are viewed with a unique significance beyond that of a normal electoral cycle, making their credibility paramount." ${ }^{3}$ 
Although the on-going conflict between the Government of the Islamic Republic of Afghanistan (GIRoA) / NATO and armed opposition groups (AOG) do not provide a conducive environment for elections, the upcoming elections are a window of opportunity for new leadership and hence an impetus for political change in the country.

A successful political transition is also a crucial component in the relations between Afghanistan and the international community, and for the continued flow of foreign aid to sustain (or soften the expected slump in) economic growth and development.

Urban civil society has been rather vocal in supporting elections. Afghan civil society activists see elections as crucial to their country's future and peace talks with the armed opposition. However, it is not clear yet where traditional power holders in rural Pashtun areas (e.g., khans, maliks, arbabs) stand in these debates. Many of them may share the opinion of the spiritual leader of the Taliban movementMullah Omar-calling the elections "a waste of time."4

A recent study found the greatest dissatisfaction with democracy and highest voter apathy among the Pashtun ethnic group. ${ }^{5}$ Some Pashtun traditional elites have publically called attention to insecurity and the subsequent disenfranchisement of part of the population. Instead, they suggested postponing the 2014 elections until the security situation improves.
Despite these concerns, some traditional elites are actively engaging presidential candidates, working to reactivate networks or planning to run as candidates for provincial councils. They have highlighted the negative impact and repercussions of not holding elections.

This paper-based on interviews with community leaders in Paktia and Khost during June and July of 2013-aims to improve our understanding of how Southeastern traditional elites perceive electoral democracy; on what grounds they take decisions regarding the electoral process in terms of voter mobilisation and running for office; and whether such elections are important to tribal politics. ${ }^{6}$

In the next section we will discuss past election experiences before differentiating between presidential, parliamentary and provincial council elections. Presidential, parliamentary and provincial council elections have different political dynamics and effects on the engagement and decisions tribal elders take. We need to take account of these distinctions to arrive at a nuanced picture of election dynamics. In Section 3 we look more closely at the upcoming elections scheduled for April 2014.

\section{Perceptions of Past Elections: good, Bad or Ugly?}

In our understanding, in Loya Paktia tribal elders are still relevant political actors. ${ }^{7}$ They played important roles in previous 
presidential, parliamentary and provincial council elections, organizing local security arrangements, and partaking in political negotiations and deals to establish alliances for specific candidates. In the upcoming 2014 elections, Khost and Paktia are among the provinces of the Pashtun belt (alongside Nangarhar) where the strength of tribal structures could make a higher voter turnout in many districts possible.

To many traditional elites democratic elections in Afghanistan, agreed to as part of the Bonn Peace Accord, have always been closely linked to the promise of aid and development resources. This link, echoed in the strategic communications by UN Deputy Secretary-General Jan Eliasson, constitues a pillar of the post-Taliban "social contract." Elections, and political representation, Presidency and Parliament (more so than Provincial Councils), are thus seen as part of a bargaining process over access to international reconstruction and development assistance, ${ }^{8}$ both of which would produce connectivity between the tribes, the new Afghan government and the international donor community.

However, during the course of this research, traditional elites in Khost and Paktia expressed the view that the Afghan government and the international community have failed to deliver on development promises. As a result, those interviewed perceived the benefits of elections to be low and the costs to be high. Furthermore, the failure of organizing credible and transparent elections is seen as a deal-breaker, rescinding the 'social contract' between South-eastern elites and the state which failed to deliver on promises.

Thus, how elections are managed, and how much traditional elites believe they can be part of the electoral process greatly impacts traditional elites' views of the Afghan government. The result is that in rural Pashtun areas the legitimacy of election processes-and by association the Afghan state-is weak.

Lastly, the changing security environment and protracted conflict between ISAF, AOG and GIRoA deters many from participating in elections; and again the blame goes to the Afghan government for failing to provide an enabling environment to cast a vote safely.

\subsection{From International to National Election Management}

During the first presidential (2004) and parliamentary (2005) elections the international community played a considerable guiding and monitoring role. To oversee the process, UNAMA supported the Joint Electoral Management Body (JEMB) which was formed and comprised of "nine Afghan members appointed by the President and four international electoral experts appointed by the UN Special Representative of the Secretary General (SRSG) for Afghanistan". ${ }^{9}$ In hindsight, some respondents appreciated this larger oversight role of the international community, in particular the monitoring of the electoral process. ${ }^{10}$ Others did not share this assessment, 
highlighting that allegations of fraud were raised in 2004 as well. ${ }^{11}$ They further emphasized that even in 2004 security was provided everywhere and that with the exception of some women in Gardez, only men came to the polling stations. Some respondents argued that those elected had participated in fraudulent practices and had the backing of "powerful people" in GIRoA. The assessment of the 2009/2010 elections was even more damning as elections were seen as marred by fraud, and honest candidates are said to have had little chance of garnering enough votes to be elected into the Provincial Councils or Parliament.

According to some elders, UNAMA and JEMB were part of the problem, as these bodies were pressured not to report on irregularities on election-day and the vote counting process. In their assessment, UNAMA's reputation suffered considerably because of their inability to prevent irregularities during the election process. In addition, the decision to let persons suspected of war crimes run as candidates without articulating a reconciliation process negatively affected the population's perception of democracy. Last but not least, some also felt that international actors controlling elections raised important questions about the sovereignty and independence of the Afghan state.

In the 2009 Presidential and 2010 Parliamentary elections the international community played a much reduced role, with the Afghan government in charge of security provision (the Afghan National
Security Forces (ANSF)) and monitoring (the Independent Election Commission (IEC)).

Security had already deteriorated to such an extent that international organisations were not keen on wide-spread election monitoring given access limitations. Furthermore, the 2009 election also produced a substantial rift between GIRoA and the international community; while some international commentators blamed GIRoA for its inability to provide fair and transparent elections, ${ }^{12}$ GIRoA pointed to lack of support from the international community. GIRoA's complaints included: insufficient international pressure on neighbouring countries and UNAMA officials openly siding with candidates. To many Afghans, who have seen Karzai as an ally of the international community, this public display of differences was damaging to the democratic project.

Irregularities in past elections have thus taken their toll, and not just in the faith elders have in future elections. President Karzai in his speech at the Loya Jirga of November 2013 made it clear that he is not keen on repeating the 2009 election fiasco. He thus called on the international community to work for fair and transparent elections in Afghanistan by providing sufficient security before he would sign the Bilateral Security Agreement (BSA).

Furthermore, a recent study showed that less than half of all Afghans (39\%) are satisfied with democracy in their country (16.5\% are very satisfied, and $22.5 \%$ fairly 
satisfied), while one-third (33\%) said they are dissatisfied (with $4 \%$ believing there is no democracy in their country), ${ }^{13}$ and nearly another third (29\%) sitting on the fence - either showing no opinion or refusing to respond. ${ }^{14}$ Some respondents highlighted that there is a lack of transparency in how the final election results are produced. Some see them as the result of political forces rather than a neutral vote counting.

\subsection{Changing Security Environment}

The security environment is a main factor shaping election processes. All respondents agreed that the 2004 and 2005 elections took place under better security conditions than in 2009. With ANSF still weak, elders played an important role in organizing security around polling stations and for election staff and candidates on election tours.

In an unique government-community cooperation, and with funding channelled through UNAMA and the Governor's office, traditional tribal police (arbakai) were mobilised during both the 2004 and 2005 elections to assist Afghan National Police in providing security for polling stations in four South-eastern provinces (Paktia, Paktika, Khost and Ghazni). ${ }^{15}$ "In the four provinces, the combined arbakai was 10,000 guards as compared to fewer than 2,000 police," ${ }^{16}$ prompting tribal elders to argue that the government lacked the ability to conduct the elections without their help. By assuring security and the functioning of polling station even in some insecure rural areas, tribal elders helped to create the conditions for elections.

By 2009, however, traditional power holders found themselves in a complicated situation considering the Taliban expansion and concurrent declining credibility of the Afghan government. In some areas the Taliban pressured traditional power holders to refrain from working with GIRoA. More areas were difficult to access than in 2004, and election participation subsequently dropped.

\subsubsection{Women's Participation}

Perceptions of worsening security have also affected women's participation as voters and candidates. Women's voter turnout in Afghanistan has fallen steadily since 2004. In that year, roughly 2.7 million women turned out; ${ }^{17}$ whilein 2010 only 1.6 million women did so. ${ }^{18}$ Several, interrelated reasons seem to have contributed to this decline. Nationwide, the IEC proved unable to staff 650 polling stations for women. At many of these polling stations, the IEC had to employ male staff because not enough women had been recruited.

In 2004 and 2005, women's participation in Loya Paktia was not necessarily due to conviction but the realization of tribal elders that in a one person-one vote system denying women the right to vote would penalize the community. This was important for both Presidential, and Provincial Council elections: in the former, the Loya Paktia tribes could show publically how many votes they had earned for the President (and formulate 
demands accordingly); in the latter, the women's votes were relevant in order to ensure certain candidates made it into office. In sum, the tribe that did not mobilize (or even allow) its women's vote would be penalizing itself.

Women can face substantial cultural barriers when seeking to vote as well as running as candidates. Particularly in rural areas, a substantial number of people seem to be unaware that women have the right to vote. ${ }^{19}$ Perceptions of worsening security have only reinforced the restrictions on women from leaving the house. However, insecurity only partly explains dropping participation in elections. There are also other practical problems, such as poor transportation, which indicate insufficient preparation for women's participation as voters and candidates. Furthermore, the general disillusionment with elections affects women just as much as men.

\subsection{Different Types of Elections}

To understand how Pashtun traditional elites interact with elections, different types of elections (e.g., Presidential, Parliamentary, and Provincial Council elections) need to be distinguished as they involve different political dynamics and dimensions (national or provincial).

\subsubsection{Presidential Elections}

Tribal elders spoken to highlighted that the presidential campaigns of 2004 were dominated by reconstruction and development projects. They expressed disappointment in this regard as the promises made in 2004 in terms of reconstruction and development projects were never, or only partly, fulfilled. This has caused a degree of disillusionment among tribal elders and communities.

According to tribal elders from Loya Paktia, the government has not lived up to its side of the bargain. Similarly, tribal elders from Khost recalled how Hamid Karzai had promised "to work for Khost" and spoken of hydro power projects, industrial parks, paving the Khost-Paktia road (which is still under construction), water intakes for irrigation, bridges, and making an international airport which is crucial for Khost with its large labour migrant population in Gulf Arab countries.

As campaign promises of reconstruction and development projects did not materialize as expected, support for President Karzai waned. Furthermore, the speeches of the 2009 Presidential elections increasingly focused on the ethnic identity of Pashtun, Tajik or Hazara candidates. Elders interpreted this shift as an intentional distraction from the failure to keep election promises.

Some tribal elders from Loya Paktia (among them Tajiks and Pashtuns) argued that in the second round of the 2009 Presidential elections, Ramadan Bashardost, an ethnic Hazara, was widely seen as the most credible candidate. However, Bashardost could not mobilize enough votes to win and was opposed by powerful persons. Similarly Pashtuns tended to support Karzai because he was Pashtun and because many were wary of 
rival candidates. At the same time, many Tajiks voted for Abdullah to prevent Karzai from staying in power. In sum, the Presidential elections of 2009 were strongly fought along ethnic lines - with Pashtun disapproval of a non-Pashtun as President, while also igniting an ethnic entrepreneurship that had already begun to fragment Afghanistan during the jihad and the mujahideen years.

Another important factor which shapes the Pashtun traditional elites' perception of Presidential elections is the strong conviction among the population that Presidential elections are pre-determined by the international community, particularly the US. UNAMA is not seen as a body independent of US interests. Support for a particular candidate is thus also shaped by access to the international community which is expected to translate into development and reconstruction projects and funds. The perception that foreign powers predetermine elections is not limited to the Presidency; Parliamentary candidates too are assumed to be supported by foreign countries like Iran, Pakistan, or India much the same as foreign countries were supporting particular provincial governors and provincial chiefs of police (e.g., the Dutch and UK insisting on the respective removal of the late Jan Mohammad Khan in Uruzgan and Sher Mohammad Akhundzada in Helmand). Consequently, many traditional elites do not think that it is voting which decides elections. Rather, the election process is manipulated to fit the candidate(s) who are pre-selected.
As in past elections, the international community is assumed to determine the winner of the 2014 presidential elections. However, while in 2004 and 2009 there was the strong sentiment that Karzai was the favourite of the international community - which influenced the vote of many - in 2014, (with no incumbent and as many as eleven candidates) the choice is not as clear. If the field of candidates is not reduced in Spring, the vote of Loya Paktia could be much more divided.

\subsubsection{Provincial Council Elections}

Provincial council elections will be held together with the presidential elections in April 2014. Traditional power holders spoken to had different opinions about the power of Provincial Councils (PC), how relevant they are for redistributing resources to local communities, and consequently how important they are to tribal politics.

The usefulness of a PC is an expression of the members comprising it. If the members are already informally powerful, they can use this power to turn the provincial council into a powerful body. This was the case in Kandahar during the time of Ahmed Wali Karzai, and in Nangarhar, Herat, and Baghlan.

But in Khost and Paktia, the more powerful traditional elites have not systematically invested their power in the Provincial Councils. Major tribal leaders are either in informal shuras or in the Parliament, which is considered more prestigious. However, even in Parliamentary elections it is not the traditional elites but leaders with a 
background in the People's Democratic Party of Afghanistan (PDPA) or a mujahideen faction as well as wealthy persons who dominate, although there is overlap between these groups and tribal leaders. The perception prevails that Provincial Council positions benefit mostly the elected members but do not constitute an important source of power or base to construct tribal leadership. This seems to be linked to the fact that few resources are redistributed from the Provincial Council to local communities.

Based on the experience with elections in $2004 / 2005$, and strongly reinforced in 2009, traditional elites view Provincial Council composition not to be based on their capacity as politicians or the popular vote. Instead, they consider it pre-selection or investment (bribes). The costs for running in elections, both in monetary and symbolic terms, are considered to be high. At the same time, the benefits of the Provincial Council position are unclear or considered to be negligible.

Furthermore, the elected Provincial Council members use their positions to recover the costs expended during the election process. Monetary expenditures cover election mobilization, which itself includes costly gatherings where the main purpose is to feed the maximum number of people by offering rice, meat, and even covering transportation costs to the venue site. This expenditure is a display of wealth and symbolic power which, obliges a response in terms of electoral support and constructs a political network. Money costs further include expenditure on election- day through bribing election officials such as election monitoring officers and those involved in counting votes directly or hiring people who can exert pressure on the election officials.

Once the elected Provincial Council members have recovered their expenses, they siphon off some resources for their personal benefit - a sort of return of investment. It is difficult to make a general statement on the amount of this return on investment (which is also affected by various levels of personal greediness), but it is safe to say that Paktia has not been a major recipient of development funds and the level of corruption does not seem to have attracted the attention of the traditional elites.

Since the Provincial Councils actually do not dispose of that many distributable resources, they are not considered to be a hugely important body in Paktia. In fact, those who are wealthy or wish to be so find other avenues: business, principally of the kind that requires investment in theaters of accumulation at the Kabul level. This makes parliamentary elections more attractive. Incidentally, considering that a member of the Provincial Council, (usually the candidate with the most votes) is sent to the Parliament, it creates a residual interest in the Provincial Council elections that they do not seem to otherwise possess.

In addition to not facilitating access to material resources, the potential threat to reputation is another reason traditional elites generally forego much interest in 
Provincial Council elections, as "good persons" would not run for a position necessitating money expenditure.

Thus the most interesting point about Provincial Councils in Khost and Paktia is in terms of networking with the government and administration. It provides privileged access and yields knowledge for navigating government administration. This can become useful for community members when they have concrete problems with the government or issues which need government intervention, for example in case of a traffic accident or when a person requires an ID card or some sort of official document. Here, Provincial Council members can direct an applicant to the right persons or speed up a process. While this is useful, it does not really constitute a major source of power, but, in fact an abuse of power. More interesting in the latter regard is that government networks provide privileged access to plots in government housing schemes. Gardez and Khost City have seen rising urbanization and housing close to provincial centers are a major theater of accumulation and redistribution.

The status of the PC also depends on what kind of a working relationship it has with the provincial governor. Traditional power holders pointed out that in Khost province, the $P C$ is relatively powerful because it has a good relationship with the Provincial Governor (PG) while in Paktia the PG does not engage the $P C$, thus rendering the council less powerful.
As will be discussed further below, despite the fact that the PC elections may not be the main site where tribal politics are played out, many current members are running for re-election. Furthermore, a number of young civil society activists are also running for election. Despite doubts over the power of the PCs, some people still think that it is worth running to increase their public profile and construct a political career.

\subsection{Elections as a Cause of Political Tensions}

Elections are also a source of tension when they create political imbalance between tribes. This can occur when a tribe is overor under-represented (relative to its population size in a given province) in the $\mathrm{PC}$, thereby damaging the fragile balance of inter-group relations.

Political actors in Loya Paktia are notoriously self-conscious about the local balance of power between different groups, not only on the level of overall tribes (e.g. Mangal, Zazi, etc.) but also the different sub-tribes. This is because traditionally, power in predominantly Pashtun and tribal areas is shared, and positions allotted to any given tribe or subtribe on a shura (such as the PC) or jirgaor to receive benefits from government/external funds-is determined in proportion to the group's population size and land holdings. ${ }^{20}$ With the introduction of elected offices, distributing power within a given tribe can be achieved through rotating official positions among sub-tribes. However, as 
the following example shows, the electoral process can become a divider when it disturbs the tribal balance of power.

For example, the Ahmadzai tribe in Ahmad Aba, Paktia, are structured into two subtribes concentrated in two areas: the area around the main road from Gardez, and the Machalgho area. When the 2003 Constitutional Loya Jirga was to be held, the Ahmadzai decided to send a relatively young but well educated person from the 'road area'. Following this principal of rotation, this meant that the entire tribe would back a candidate from the Machalgho area for the PCseat. The problem emerged when the young representative who had gone to the Constitutional Loya Jirga (and had built up his own networks in Kabul) decided to run for the PC. Rather than backing an Ahmadzai seat the competing sub-tribe, feeling snubbed, put up their own candidate thereby splitting the Ahmadzai vote - neither candidate won the elections. Because of this internal division the Ahmadzai tribe in Paktia lost out vis-à-vis other tribes. This has also made it clear that those running for public office are not necessarily doing so with the backing of their tribe.

\section{Outlook on 2014}

Based on past experiences, traditional elites in Loya Paktia see the security environment and election monitoring stand out as main concerns for the 2014 elections. All respondents expect insecurity to be worse in 2014 as the presence of AOG in Loya Paktia has grown in recent years. Traditional elites have been pressured to cut ties with GIRoA.

In this scenario, polling stations are not expected to open in many places and voting will be restricted to urban areas. One respondent from Paktia pointed out that the voter registration process was already foreshadowing this as it has hitherto been concentrated in the urban centres such as Gardez and Chamkani. ${ }^{21}$ The voter registration process is thus already disfavouring people living in more remote areas.

Some are concerned that polling stations will not be opened in areas deemed too insecure for voting and thus disenfranchise a large section of the population. This could then lead to political violence. ${ }^{22}$ Following interventions by First Vice President Marshall Fahim and Zulmay Khalilzad to address such concerns, debates are increasingly closing in on the idea of a national consensus as a way towards a peaceful transfer of power which would satisfy both the need for elections and prevent or at least reduce political violence. $^{23}$

This makes for much scepticism among elders interviewed. Their overall preference seems to be to postpone the 2014 elections, form an interim government which would lead peace talks with the insurgency, and then deliver a more transparent election process. ${ }^{24}$ These elders' point regarding current insecurity is well taken but postponing the election will likely have negative consequences. As the speech by Eliasson made clear, the 
elections are part of a deal for continued international financial and political support for Afghanistan and traditional elites cannot ignore this.

\subsection{National Consensus? Transitional Authority?}

Security problems and political violence around the 2014 elections are risks which have prompted discussions among international and Afghan political leaders and analysts that are focusing on options for national consensus and transitional authority. $^{25}$

The idea of such consensus is to reduce the number of competitors and vote-splitting which could then lead to political violence. This idea is not very different from primaries where each party determines the representative candidate via a competitive process.. However, as regards national consensus in the Afghan context, the discussion seems to be to reduce the number of candidates for presidential elections to one.

According to AAN analyst Gran Hewad, First Vice President Marshal Fahim and later Khalilzad used the term to designate a process that would "guarantee a peaceful transfer of power and prevent violence after the second and final term of the current president ends". ${ }^{26}$ There are doubts about the possibility of reaching a pre-election political consensus. "In a country where politics-of-patronage is dominant, the concept of reaching consensus on such a vital and sensitive matter is a mirage. Historically, Afghan political leaders -whether part of the regime or the opposition - have been fragmented and have rarely agreed on a common political platform on which to unite. $^{27}$

The option of a pre-election political consensus was also advocated for in a May 2013 testimony before the US Senate Foreign Relations Committee: "the only way to significantly reduce the incentive for cheating in the 2014 election is to work seriously to build political consensus among Afghan constituencies ahead of time." 28 Furthermore, a recent Foreign Affairs article has discussed this idea and the "national consensus" groups which are forming around this option. ${ }^{29}$

Some tribal elders from Loya Paktia advocated for a transitional authority rather than national consensus as such, because the latter does not solve the fundamental problem of security. Even if competition is reduced to a few candidates, security is still essential to hold elections. As one elder explained: "If there are elections in 2014 the insurgency will continue. The priority should be peace between GIRoA and the Taliban; then elections should be held when there is no insecurity. Instead of elections, a temporary administration would be better which should prepare peace talks and then elections which can be transparent."

However, the transitional authority option seems to have little traction with many international as well as Afghan political leaders. There is also no guarantee that a transitional authority could produce better security and a more transparent process. 
Furthermore, the ideas of national consensus and transitional authority may also have been floated in the media to gauge reactions by both Afghan citizens and international actors.

\subsection{Who is Running?}

Despite concerns over the security environment and voter fatigue, eleven candidates are currently on the IEC Presidential candidate list. ${ }^{30}$ In Paktia and in Khost 68 and 62 candidates, respectively, are running for the 2014 PC. In some areas tribal elders have publically voiced support for the elections and are forming and participating in election alliances. In Tanai District of Khost, for example (one of the most secure and antiAOG districts of the province), tribal elders said that if the transparency of the elections were ensured, "our people will not only participate in the process but we will provide volunteers for security maintenance." ${ }^{31}$

At the same time, discussion with respondents about the 2014 Provincial Council candidates' lists confirmed that the major tribal figures and traditional elites are not running. The best-known candidates are those who are already Council members. Many of the other candidates are not well-known and/or are young. Many respondents expect the current Council members to be re-elected, partly because they can reactivate the networks from previous elections while new candidates have to create them.

Youth is not necessarily a disadvantage in terms of actual capacity, particularly when dealing with development issues. One respondent commented that many of the elders are not accustomed to the knowledge required in the NGO/development world (literacy, project forms, contracts, memorandums of understanding etc.).

That being said, many NGO workers are relatively young themselves, in a society where age is a crucial status marker. This might lead voters to choose a more seasoned person. Yet, even if not elected, for some youths, the election process itself is a way of making their name more known and thus a way of constructing a political career.

\section{Conclusion and Recommendations}

The 2004 elections had the potential of starting a process which would bring the Afghan government, the population and the international community together. However, elections turned into a divider as perceptions of widespread fraud, disappointment over unmet campaign promises in terms of reconstruction and development projects, and ever increasing insecurity which put elders' lives at risk, has reduced the willingness of tribal elders to organize security and campaign in the 2014 elections.

Furthermore, the conviction that official election figures are not the result of the voting but of political forces, pre-selection or costly investment in the election process, and the possibility that elections will be postponed or called off altogether, 
are contributing to disenchantment with the value of elections. Nonetheless, and while official election campaigning has not started yet, the eleven Presidential candidates have started to reach out to traditional elites and civil society networks as well as wealthy community figures in Khost and Paktia, rekindling networks and testing their grounds.

\section{Renew the role of international organizations in election monitoring?}

Some elders asked for a stronger involvement of international organisations in general, and the UN in particular, in election monitoring. As an example they referred to the elections of 2004 . This is somewhat contradictory with their complaint vis-à-vis UNAMA to curb election fraud. The recommendation thus is a mixed message, which dooms the international community if they do curb election-related corruption (as being perceived as meddling) as well if they don't (by being perceived as not doing their job).

This recommendation also raises important questions about national sovereignty, which features strongly in the rhetoric of Afghan politicians, but also elders. However, the same can be said of many aspects of governance in Afghanistan, particularly the fiscal base of the government. As long as $80 \%$ of the government budget is foreign funded, national sovereignty is 'shared sovereignty'. The point to retain is that the traditional elders have greater trust, even if at a low level, in the UN in terms of monitoring the election process than in the IEC.

\section{Strengthen (independent) vetting process for elections candidates}

Respondents suggested major changes to the process of vetting candidates eligible for office. They also highlighted that this process should be monitored by the UN. As an example, tribal elders might introduce candidates with the help of the common people to the UN and provide candidates' complete biographies, including education, wealth, family relations, and role in past conflicts. The UN would then vet the candidates' background.

\section{Facilitate dialogue platforms and consensus building}

A frequently repeated recommendation (not limited to elections) has been the dire need for public debate which would raise public awareness and interest in the election process. This should include a shift of focus in election debates away from the candidates' ethnicities to the candidates' strategies and political programs and policies. As one elder stated, "The people want to hear a candidate who has a program and policies." ${ }^{32}$

Additionally, there is dire need for national dialogue to bring people from different regions of the country together. In the words of one tribal elder, "The people of Khost should go to the north and sit and discuss with the people and vice versa. Now the north and the south are distanced from each other - they talk about each other but not with each other." ${ }^{\prime 33}$ 


\section{Renew the role of tribal elders and religious leaders in civic education and public awareness}

In a repeat of their role in $2004 / 5$, elders primarily see their part to play in civic education. According to them, the early elections showed that tribal elders can play an important role as communicators and opinion leaders, and in shaping the public opinion of what criteria a good candidate should have and whom to vote for. One elder stated that "Tribal elders will go to the mosque and give messages that voting is a right and a duty, that it is the right of the people to vote a trusted person and that if they do not vote they will pay in the afterlife because it is their duty to replace the corrupt with the good." ${ }^{34}$

At the same time, the large number of young candidates with a civil society background running for provincial council in 2014 raises the issue of a potential generational change. While traditional elites seem to prefer to invest their power either in informal structures or at the parliamentary level, the Provincial Council mandate of oversight over provincial level policy could open an interesting avenue for a new generation of leaders. This is even truer considering the importance of new skill sets and knowledge linked to the development and reconstruction sectors.

\section{Endnotes}

1 http://www.tolonews.com/en/afghanistan/11246online-exclusive-an-in

http://www.un.org/apps/news/story.asp?NewsID=45334 \#.Ue4hRm2QNec

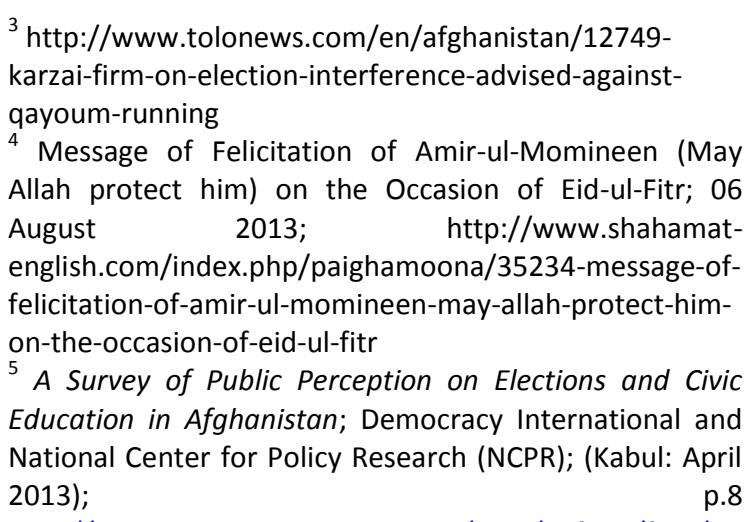
http://democracyinternational.com/sites/default/files/EC E\%20Survev\%20Report.pdf,

${ }^{6}$ TLO spoke to 28 elders from Khost and Paktia to understand their positions vis-à-vis the upcoming elections.

${ }^{7}$ But not the only ones: they exist alongside or overlap with factional networks or civil society groups and organizations.

8 Focus group discussion with Elders from Khost, July 2013

${ }^{9}$ National Democratic Institute The 2009 Presidential and Provincial Council Elections in Afghanistan, p. 8.

10 Focus group discussion with elders from Paktia province, July 2013

${ }^{11}$ SIGAR Audit 10-16 Governance/Elections;

12 Sarah Chayes. Prospects for Afghanistan's 2014 Elections

${ }^{13}$ A Survey of Public Perception on Elections and Civic Education in Afghanistan; Democracy International and National Center for Policy Research (NCPR); (Kabul: April 2013);

p.8

http://democracyinternational.com/sites/default/files/EC E\%20Survey\%20Report.pdf,

${ }^{14}$ A Survey of Public Perception on Elections and Civic Education in Afghanistan-Data Report; Democracy International and National Center for Policy Research (NCPR); (Kabul: April 2013); http://democracyinternational.com/sites/default/files/EC E\%20Survey\%20Data\%20April\%202013\%20-\%20final.pdf

${ }^{15}$ Susanne Schmeidl and Masood Karokhail (2009) "The Role of Non-State Actors in 'Community-Based Policing' An Exploration of the Arbakai (Tribal Police) in SouthEastern Afghanistan," Contemporary Security Policy, Vol.30(2):318-342

${ }^{16}$ Ibid, pp.326-7

${ }^{17}$ Already in 2004 and 2005, reports of fraud in relation to the women's vote were common.

18 Lough, et al. "Equal Rights, Unequal Opportunities: Women's Participation in Afghanistan's Parliamentary and Provincial Council Elections" (Afghan Research and Evaluation Unit, 2012) at 11.

${ }^{19}$ Nawabi, et al. "Barriers and Opportunities for Women's Participation in the Election Process in Afghanistan" (International Foundation for Electoral Systems, 2009) (at http://www.ifes.org/Content/Publications/Opinions/200 
9/May/Barriers-and-Opportunities-for-Womens-

Participation-in-the-Election-Process-in-Afghanistan.aspx)

${ }^{20}$ More specifically, there are various measures here, such as number of households, number of men that can mobilised for war etc.

${ }^{21}$ Focus group discussion with elders from Paktia, July 2013.

http://www.elections.pajhwok.com/en/2013/05/14/khos t-elders-warn-election-boycott

http://www.afghanistan-analysts.org/elections-ornational-consensus-which-one-wins; According to AAN analyst Gran Hewad First the latter used the term to designate a process that would "guarantee a peaceful transfer of power and prevent violence after the second and final term of the current president ends".

${ }^{24}$ Focus group discussion with elders from Paktia and Khost, July 2013.

${ }^{25}$ One question is whether ALP will be pulled into providing election security. According to respondents, in some areas the "ALP is very effective, much more than ANP and ANA. They know the area well because they are locals."

26 http://www.afghanistan-analysts.org/elections-ornational-consensus-which-one-wins;

http://8am.af/1391/12/02/khalilzad-8am-interview-

2014-afghanistan-future/

27 http://8am.af/1391/12/02/khalilzad-8am-interview2014-afghanistan-future/

${ }^{28}$ Sarah Chayes, Testimony Senate Foreign Relations Committee, 21 May 2013. See http://carnegieendowment.org/2013/05/21/prospectsfor-afghanistan-s-2014-elections/g5il

${ }^{29}$ Foreign policy

${ }^{30}$ http://www.tolonews.com/en/afghanistan/12791final-list-sees-presiden 31

http://unama.unmissions.org/default.aspx?ctl=Details\&t abid $=12333 \&$ mid $=15879 \& \mid$ tem ID $=36579$

${ }^{32}$ Interview with Khost elders, June 2013

${ }^{33}$ Interview with Khost elders, June 2013

${ }^{34}$ Interview with Paktia elders, June 2013 